\title{
Rehabilitation programs after the implantation of transfemoral osseointegrated fixations for bone-anchored prostheses: A protocol for a scoping review
}

\author{
Sofie Vertriest ${ }^{(1)}$, Shanthan Pather ${ }^{(2)}$, Peter Sondergeld ${ }^{(3)}$, Mary-Anne Ramis ${ }^{(4)}$, Laurent Frossard ${ }^{(5,6)}$ \\ ${ }^{(1)}$ Department of Physical and Rehabilitation Medicine, University Hospital, Belgium \\ ${ }^{(2)}$ School of Mechanical, Manufacturing \& Medical Engineering, Queensland University of Technology, Australia \\ (3) Library, Queensland University of Technology, Australia \\ (4) Centre for Evidence Based Healthy Ageing (CEBHA), Queensland University of Technology, Australia \\ ${ }^{(5)}$ School of Exercise and Nutrition Science, Faculty of Health, Queensland University of Technology, Australia \\ ${ }^{(6)}$ School of Health and Sport Sciences, University of the Sunshine Coast, Queensland, Australia
}

Manuscript as published in "Vertriest S, Pather S, Sondergeld P, Frossard L. Rehabilitation programs after the implantation of transfemoral osseointegrated fixations for bone-anchored prostheses: a scoping review protocol. JBI Database of Systematic Reviews and Implementation Reports. 2017. 15(2):607-619

http://journals.lww.com/jbisrir/Fulltext/2017/03000/Rehabilitation_programs_after the implantation_of.5.as $\underline{\mathbf{p x}}$

\begin{abstract}
This scoping review aims to answer two research questions (1) What is the clinical indicators' intravariability for both screw-type (Q1) and press-fit fixations $(\mathbf{Q} 2)$ ? (2)What is the clinical indicators' intervariability between screw-type and press-fit fixations (Q3)? The objectives of this scoping review are therefore, to characterize the rehabilitation programs performed by individuals with transfemoral amputation following the implantation of an osseointegrated fixation for bone-anchored prostheses; to describe partial weight bearing exercises in each rehabilitation program for screw-type and press-fit fixations; and to compare key rehabilitation parameters for each of these exercises within each program for screw-type and press-fit fixations (intra-variability) as between programs for screw-type and press-fit fixations (inter-variability). This scoping review will consider studies involving individuals with transfemoral amputation fitted with a bone-anchored prosthesis using either screw-type or press-fit osseointegrated fixation. This scoping review will examine the concepts of intra-variability and inter-variability in clinical indicators of the rehabilitation programs for screw-type and press-fit fixations fitted to bone-anchored prosthesis of individuals with transfemoral amputation. This scoping review will consider studies providing broad and specific clinical elements underlying the rehabilitation program aiming at promoting bone remodeling around osseointegrated fixation. Also, this scoping review will consider studies relying on measurements conducted in different settings. This scoping review will consider a broad range of study designs in order to capture the concepts outlined above. The search strategy will aim to find both unpublished and published studies.
\end{abstract}

Keywords

Direct skeletal attachment; Osseointegrated fixation; Prosthesis; Rehabilitation program; Transfemoral amputation

Review question

The primary objective of this scoping review is to characterize rehabilitation programs performed by individuals with transfemoral amputation following the implantation of screw-type or press-fit osseointegrated fixations for bone-anchored prostheses.

The secondary objective of this review is to describe partial weight bearing exercises including static and dynamic exercises as well as use of walking aids in each rehabilitation program for screw-type and pressfit fixations.

The third objective of this review will be to compare 
key rehabilitation parameters for each of these partial weight bearing exercises (e.g., type of training prosthesis, loading time and progression, monitoring of loading, loading direction, instructions given to patients, the use of loading regulators) within each program for screw-type and press-fit fixations (intravariability) as between programs for screw-type and press-fit fixations (inter-variability).

The specific review questions are:

- Review Question 1: What are the intravariabilities within rehabilitation programs corresponding to the differences in rehabilitation parameters within programs for each screw-type (Q1) and press-fit (Q2) fixations?

- Review Question 2: What are the intervariabilities between rehabilitation programs corresponding to the differences in rehabilitation parameters between programs for screw-type and press-fit fixations (Q3)?

\section{Background}

\section{Prosthetic attachment: Shortcomings of current methods}

Typically, individuals with transfemoral amputation could be fitted with a socket suspended to the residual limb enabling attachment of prosthesis. This method of attachment often causes discomfort leading to a significant decrease in quality of life. The most frequent issues are related to the skinsocket interface (e.g., blisters, allergies), lack of trust in prosthesis due to insecure suspension (e.g., variation of residuum volume, excessive sweating), challenging attachment and detachment of the prosthesis as well as compromised sitting comfort. ${ }^{[1-7]}$ Furthermore, individuals with particularly short residuum experience further challenges to achieve suspension that could limit mobility of the hip joint and use of their prosthesis, bounding them to a wheelchair.

\section{Bone-anchored prosthesis: a solution}

Problems with socket-suspended prostheses led to the development of, so-called, osseointegrated fixations for bone-anchored prosthesis. ${ }^{[8-26]}$ This method of prosthetic attachment is now commonly accepted as a viable alternative to socket-suspended prostheses, particularly for young, active and nonvascular individuals with limb loss. Commercial osseointegrated fixations currently available include a medullar part directly connected to the femur, and a percutaneous part enabling external attachment of the prosthesis. Typically, both parts are surgically inserted following a two-step procedure.

Fixations with a medullar part relying on the screwtype design were initially developed. These cylindrical with threaded outlier fixations, inherited from dental implants, are screwed in the residual femur. They are the most common and acknowledged intervention (e.g., FDA approval for OPRA system). ${ }^{[18-21,}{ }^{27-31]}$ However, fixations with a medullar part relying on press-fit design have emerged over the last decade and they are increasingly used. $^{[11-15,}$ 32, 33] These fixations cylindrical with rough surface comparable to hip joint implants are hammered into the residual femur. Furthermore, several other devices are currently at various stages of development, particularly in Europe and the United States. ${ }^{[14,16,17,22-25,34-49]}$

Figure 1. Schematic representation of the residuum (A) of an individual with transfemoral amputation using conventional method of prosthetic attachment relying on socket $(B)$ in contact with the skin (Left side) or bone-anchored prosthesis (BAP) relying on osseointegrated fixation (C) including a medullar part inserted into the femur (D) and percutaneous part (E) protruding the residuum (Right side) each connecting to the rest of a prosthesis (F).

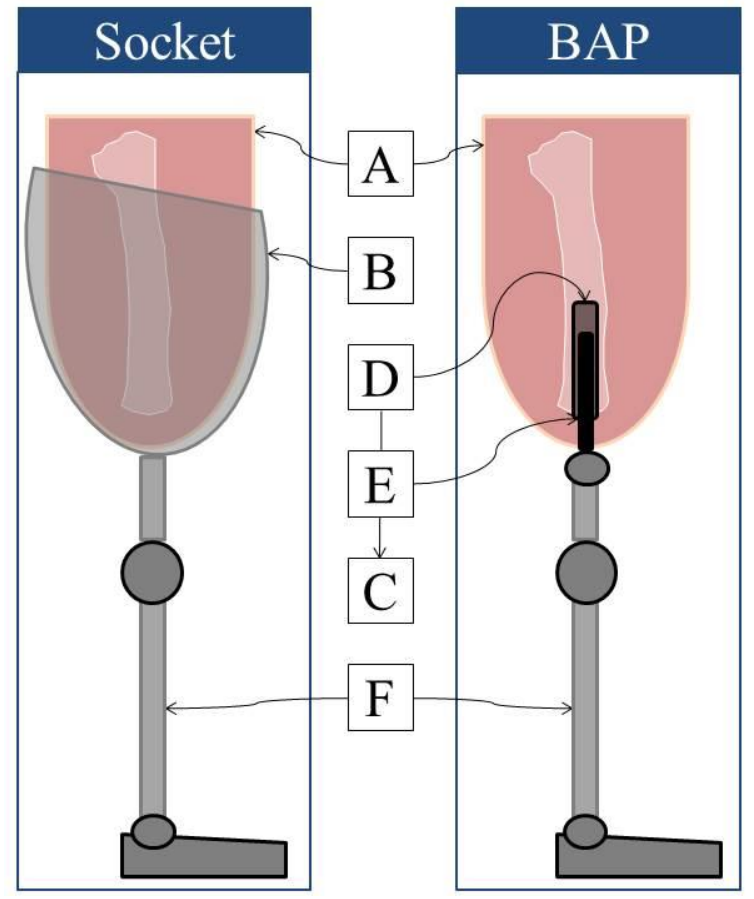

Clinical outcomes: benefits overcoming harms

Level of evidence about clinical outcomes of boneanchored prostheses varies between designs. Several 
cohort studies have focused on one or more particular clinical benefits (e.g., quality of life, prosthetic use, body image, hip range of motion, sitting comfort, ease of donning and doffing, osseoperception, walking ability). ${ }^{[15,18,21,27,28,31,32,50-57]}$ Other studies focused on specific harms (e.g., implant stability, rate of infection, effects of a fall). ${ }^{[15,18,30,58-62]}$ Altogether, the literature demonstrated that this method of attachment allows amputees to sustain extended daily activities. ${ }^{[33-55,}{ }^{63-66]}$ Overall, bone-anchored prostheses enhance markedly quality of life while presenting acceptable risks.

\section{Previous reviews: research gap}

To date, only a handfull of systematic reviews synthesizing descriptive information and/or quantitative data about bone-anchored prostheses are currently available.

Brånemark et al published a seminal article presenting historical developments of orthopedic osseointegration starting with the dental and facial implants, hearing aids and, finally, clinical applications for upper and lower prosthetic limb attachments. ${ }^{[19]}$ Pitkin gave an overview of the design features of the different osseointegrated fixations previously implanted in humans or animal studies. ${ }^{[8]}$ Kumar et al conducted a brief review study giving a general view about the osseoperception capability of osseointegrated fixations. ${ }^{[50,67,68]}$ Isaacson and Jeyapalina presented a review introducing the basic biological principles for attaining osseointegration and discusses the major factors for assuring successful cementless fixations. ${ }^{[69]}$ More recently, Van Eck et al performed the first attempt to systematically review clinical outcomes of boneanchored prostheses and confirmed that this method of attachment can result in a good quality of life and patient reported outcomes. ${ }^{[57]}$

\section{Need for a systematic comparative analysis of rehabilitation programs}

By definition, the success of bone-anchored prostheses relates to surgical procedures and subsequent rehabilitation programs. ${ }^{[70-72]}$ Typically, rehabilitation programs involve progressive mechanical loading aiming at promoting bone remodeling around the medullar part of the fixation. ${ }^{[73,74]}$

These programs are guided by the principle that a timely application of a suitable stress stimulates bone remodeling and gradually prepares the bone-implant unit to tolerate the mechanical loading likely to occur during activities of daily living. ${ }^{[53-55,60,61,63,64,73,75-77]}$ Consequently, early overloading might place the bone-implant interface at risk while underloading might slow down osseointegration and delay unrestricted use of the prosthesis.

This balance is achieved by combining static and dynamic load bearing exercises as well as the use of walking aids that could be evidenced by several key rehabilitation parameters such as type of training prosthesis, loading time and progression, monitoring of loading, loading direction, instructions given to patients and the use of loading regulators. ${ }^{[64,73-75,78]}$ These generic guidelines are followed after implantation of all current commercial fixations. However, each type of medullar part requires a specific surgical procedure and subsequent rehabilitation program. Clinicians are, indeed, stating significant variations in programs for different types of fixations, particularly in terms of overall duration ranging from six weeks to six months and loading progression, ranging from quasi-immediate to careful and slow loading for press-fit and screw-type fixations, respectively. ${ }^{[27,79-82]}$

A thorough exploration of these claims is essential to better comprehend potential differences in favorable (e.g., patient satisfactions, short term medical cost) and undesirable (e.g., infection, occurrence of periprosthetic factures, short and long term fixation stability, on-going medical costs) clinical outcomes between treatments. Ultimately, this understanding will have flow-on effects for patients in particular (e.g., choice for treatment, risk and benefits analyses) and, eventually, other decision makers (e.g., reimbursement policies, cost-effectiveness analyses).

\section{Scoping review to explore rehabilitation programs}

Surprisingly, typical systematic reviews and, eventually, a meta-analyses looking at the effect of rehabilitations programs on clinical outcomes (e.g., benefits, harms) are yet to be presented. This might be due to the lack of systematic differentiation of rehabilitation programs currently presented in the literature.

Consequently, there is a need for a comprehensive comparison of rehabilitation parameters of programs for both screw-type and press-fit fixations.Indeed, a scoping review characterizing rehabilitation programs with a systematic description of partial weight bearing exercises and comparison of key rehabilitation parameters for each of these exercises would be an initial step. Ultimately, such study could provide a shortlist of relevant rehabilitation parameters that should be considered as co-variables in future systematic reviews and meta-analyses. 


\section{Methods}

\section{Inclusion criteria}

\section{Participants}

This scoping review will consider studies involving individuals with transfemoral amputation fitted with a bone-anchored prosthesis using either screw-type or press-fit osseointegrated fixation.

\section{Concepts}

This scoping review will examine the concepts of:

- Intra-variability within rehabilitation programs corresponding to the differences in rehabilitation parameters within programs for each screw-type and press-fit fixations,

- Inter-variability between rehabilitation programs corresponding to the differences in rehabilitation parameters between programs for screw-type and press-fit fixations.

\section{Context}

This scoping review will consider studies describing at least one parameter of a rehabilitation program aiming at promoting bone remodeling around screwtype and press-fit osseointegrated fixations such type of training prosthesis, loading time and progression, monitoring of loading, loading direction, instructions given to patients and the use of loading regulators. Also, this scoping review will consider studies relying on measurements conducted in care facilities (e.g., in or out-patient in rehabilitation centers), experimental settings (e.g., motion analysis laboratories) as well as participants' own environment (e.g., home).

\section{Study types}

This scoping review will consider a broad range of study designs in order to capture the concepts outlined above. Such designs will include:

- descriptive observational study designs including case series, individual case reports and descriptive cross-sectional studies,

- analytical observational studies including prospective and retrospective cohort studies, case-control studies and analytical crosssectional studies,

- published articles but also book chapters, text and opinion papers as well abstracts provided for publication in conference proceedings.

We will also include narrative studies focusing on qualitative data including, but not limited to, designs such as phenomenology, grounded theory (e.g., bone remodeling), action research and basic qualitative description.

\section{Search strategy}

The search will be conducted by two reviewers. The search strategy will aim to find both unpublished and published studies in peer and non-peer reviewed sources. An initial limited search of Medline/Pubmed has been undertaken to identify articles on this topic, followed by analysis of the text words contained in the titles and abstracts, and of the index terms used to describe these articles. ${ }^{[8,19,57,68,69]}$ This informed the development of a search strategy including identified keywords and index terms which will be tailored for each information source. Furthermore, individual search strategy will be done for each database following using specific descriptors. A full search strategy is detailed in Appendix 1. The reference list of all included studies will be screened for additional studies.

The databases to be searched include:

- Medline/PubMed

- CINAHL

- Web of Science

- Google Scholar

- EMBASE

- SCOPUS

- LILACS

- ProQuest Dissertations and Theses Global Studies published in English, German, Dutch and French will be included giving the strong involvements of teams located in Lübeck (Germany) and Nijmegen (The Netherlands).

Only studies published since 1990 will be included corresponding to the year of first implantation of osseointegrated fixation to an individual with a lower limb amputation. ${ }^{[19]}$ The upper date limits will be the date when the search will be conducted.

\section{Data extraction}

The data extracted will broadly include information about concept, context, and study methods of significance to the scoping review question and specific objectives of each reference (e.g, intravariability and inter-variability of rehabilitation parameters).

As organized in the data extraction tool presented in Appendix II, the raw data extracted will describe the treatment (e.g., population, fixation, surgery) and, more importantly, the rehabilitation parameters 
specific to partial and full weight bearing exercises in each program. A strong emphasis will be put on extracting information about the type of training prosthesis, loading time, loading progression, monitoring of loading, loading direction, instructions given to patients and regulators during static load bearing exercises, as well as the type and duration of dynamic load bearing exercises alone and with walking aids.

Here, a dataset will correspond to the column of data in the data extraction tool including a series of information about a particular rehabilitation program provided within a single publication. It is more likely that a given publication will focus on limited aspects

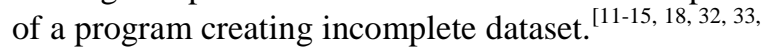
47, 49] Nonetheless, a publication detailing more than one program might generate several datasets. ${ }^{\text {[27] }}$

Two independent reviewers will complete the data extraction tool. Any disagreements that arise between the reviewers will be resolved through discussion, or with a third reviewer. Authors of papers might be contacted to request missing or additional data where required. The draft data extraction tool will be modified and revised as necessary during the process of extracting data from each study included. Modifications will be detailed in the full scoping review report.

\section{Data mapping}

All datasets collected using the data extraction tool will be collated into a single database enabling the recording, analysis and reporting of all critical information related to the review questions. First, the compiled information will be extracted and/or calculated from the raw data and will include, but not be limited to, the following rehabilitation parameters,

- Duration of each phase of the rehabilitation program (e.g., Static and dynamic load bearing exercises, use of walking aids)

- Use of regulators to establish load progression

- Load progression (e.g., loading increment over period of time)

- Monitoring of the load bearing exercises

Then, the compiled data will be grouped in relation to the type of fixation (i.e., screw-type, press-fit). Finally, the compiled data will be presented in diagrammatic or tabular form in a manner that aligns to the objective/s and scope of this scoping review. For instance, the tables and charts will report on intra-variability and inter-variability of rehabilitation parameters for both and between fixations, respectively. A narrative summary will accompany the tabulated and/or charted results and will describe how the results relate to the reviews objective and question/s.

\section{To know more}
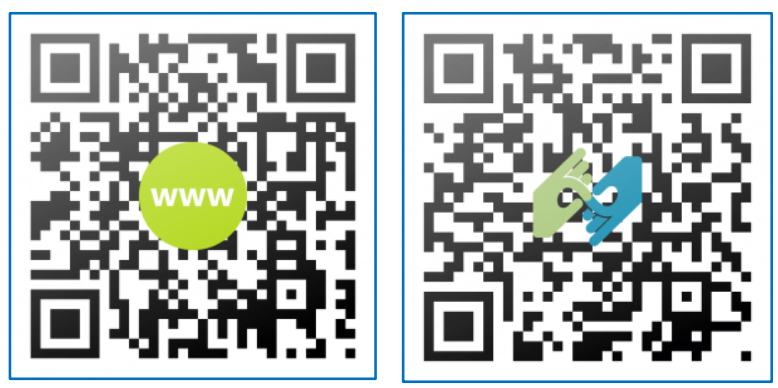

\section{Conflicts of interest}

The authors have no conflict of interest to declare.

\section{Acknowledgements}

This review will be a part of a Doctoral degree undertaken by Dr Sofie Vertriest under the supervision of Adj Prof Laurent Frossard.

The authors would like to express their gratitude to Dr Micah Peters and Dr Natalie Cutri for their contribution in the outlining of this manuscript. 
Figure 2. Overview of the search, data extraction, data mapping and review questions of the scoping review. S2: Second or final stage of surgery marking the beginning of rehabilitation program.

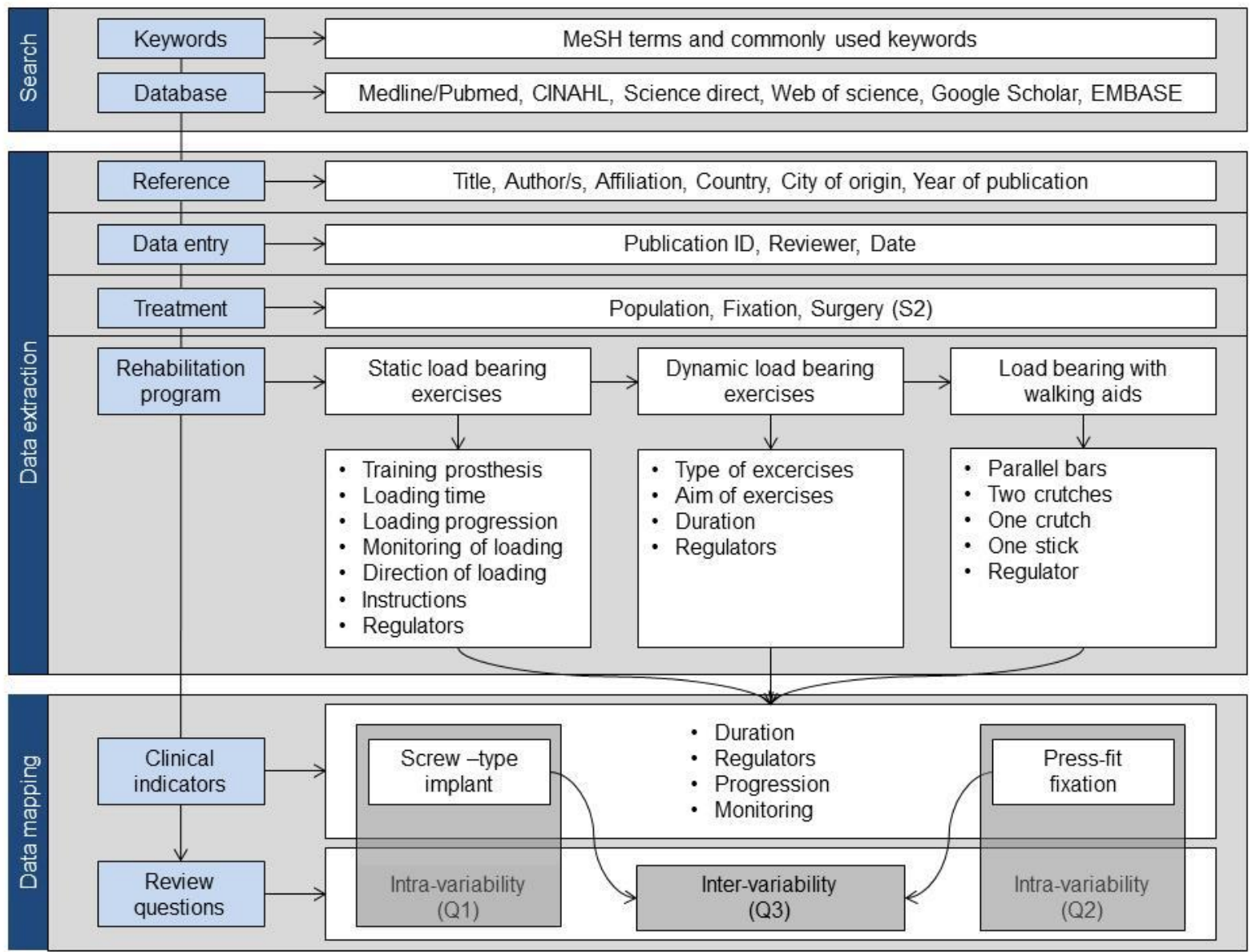

\section{References}

1. Hagberg K, Brånemark R. Consequences of non-vascular trans-femoral amputation: A survey of quality of life, prosthetic use and problems. Prosthetics and Orthotics International. 2001;25(3):186-94.

2. Lyon CC, Kulkarni J, Zimerson E, Van Ross E, Beck MH. Skin disorders in amputees. Journal of the American Academy of Dermatology. 2000 Mar;42(3):501-7. PubMed PMID: 10688725. Epub 2000/02/25. eng.

3. Meulenbelt HE, Geertzen JH, Dijkstra PU, Jonkman MF. Skin problems in lower limb amputees: an overview by case reports. J Eur Acad Dermatol Venereol. 2007 Feb;21(2):147-55. PubMed PMID: 17243947. Epub 2007/01/25. eng.

4. Meulenbelt HE, Geertzen JH, Jonkman MF, Dijkstra PU. Determinants of skin problems of the stump in lower-limb amputees. Arch Phys
Med Rehabil. 2009 Jan;90(1):74-81. PubMed PMID: 19154832. Epub 2009/01/22. eng.

5. Meulenbelt HE, Dijkstra PU, Jonkman MF, Geertzen JH. Skin problems in lower limb amputees: a systematic review. Disability and rehabilitation. 2006 May 30;28(10):603-8. PubMed PMID: 16690571. Epub 2006/05/13. eng.

6. Mak AF, Zhang M, Boone DA. State-of-theart research in lower-limb prosthetic biomechanics-socket interface: a review. Journal of rehabilitation research and development. 2001 Mar-Apr;38(2):161-74. PubMed PMID: 11392649. Epub 2001/06/08. eng.

7. Bui KM, Raugi GJ, Nguyen VQ, Reiber GE. Skin problems in individuals with lower-limb loss: literature review and proposed classification system. Journal of rehabilitation research and development. 2009;46(9):1085- 
90. PubMed PMID: 20437314. Epub 2009/01/01. eng.

8. Pitkin M. Design features of implants for direct skeletal attachment of limb prostheses. Journal of biomedical materials research Part A. 2013 Nov;101(11):3339-48. PubMed PMID: 23554122. Pubmed Central PMCID: 3758435. Epub 2013/04/05. eng.

9. Pitkin M, Raykhtsaum G, Pilling J, Galibin OV, Protasov MV, Chihovskaya JV, et al. Porous composite prosthetic pylon for integration with skin and bone. Journal of rehabilitation research and development. 2007;44(5):723-38. PubMed PMID: 17943684. Pubmed Central PMCID: 3498512. Epub 2007/10/19. eng.

10. Pitkin M, Cassidy C, Muppavarapu R, J R, Shevtsov M, Galibin O, et al. New method of fixation of in-bone implanted prosthesis. Journal of rehabilitation research and development. 2013;50(5):709-22.

11. Aschoff HH, Kennon RE, Keggi JM, Rubin LE. Transcutaneous, distal femoral, intramedullary attachment for above-the-knee prostheses: an endo-exo device. J Bone Joint Surg Am. 2010 Dec;92 Suppl 2(Supplement 2):180-6. PubMed PMID: 21123601. Epub 2010/12/09. eng.

12. Aschoff H-H, McGough R. The Endo-Exo Femoral Prosthesis: a new rehabilitation concept following above knee amputation. J Bone Joint Surg Br. 2012 September 1, 2012;94-B(SUPP XXXIX):77.

13. Rubin L, Kennon L, Keggi J, Aschoff H. Surgical management of trans-femoral amputation with a transcutaneous, press-fit distal femoral intra-medullary device: analysis with minimum 2 year follow-up. J Bone Joint Surg Br. 2012 May 1, 2012;94-B(SUPP XXI):95.

14. Hillock R, Keggi J, Kennon R, McPherson E, Clyburn T, Brazil D, et al. A Global Collaboration - Osteointegration Implant (OI) for Transfemoral Amputation - Case Report. Reconstructive review - Joint Implant Surgery \& Research Foundation. 2013;3(2):50-4.

15. Juhnke D-L, Beck JP, Jeyapalina S, Aschoff HH. Fifteen years of experience with IntegralLeg-Prosthesis: Cohort study of artificial limb attachment system. Journal of Rehabilitation Research and Development. 2015;52(4):40720.

16. Pendegrass CJ, Goodship AE, Blunn GW. Development of a soft tissue seal around bone-anchored transcutaneous amputation prostheses. Biomaterials. 2006 Aug;27(23):4183-91. PubMed PMID: 16618500. Epub 2006/04/19. eng.

17. Kang NV, Pendegrass C, Marks L, Blunn G. Osseocutaneous integration of an intraosseous transcutaneous amputation prosthesis implant used for reconstruction of a transhumeral amputee: Case report. The Journal of Hand Surgery. 2010;35(7):1130-4.

18. Berlin Ö, Bergh P, Dalen M, Eriksson S, Hagberg K, Inerot $S$, et al. Osseointegration in transfemoral amputees: the gothenburg experience. J Bone Joint Surg Br. 2012 April 1, 2012;94-B(SUPP XIV):55.

19. Branemark R, Branemark PI, Rydevik B, Myers RR. Osseointegration in skeletal reconstruction and rehabilitation: a review. Journal of rehabilitation research and development. 2001 Mar-Apr;38(2):175-81. PubMed PMID: 11392650. Epub 2001/06/08. eng.

20. Eriksson E, Branemark PI. Osseointegration from the perspective of the plastic surgeon. Plastic and reconstructive surgery. 1994 Mar;93(3):626-37. PubMed PMID: 8115525. Epub 1994/03/01. eng.

21. Branemark R, Berlin O, Hagberg K, Bergh P, Gunterberg B, Rydevik B. A novel osseointegrated percutaneous prosthetic system for the treatment of patients with transfemoral amputation: A prospective study of 51 patients. The bone \& joint journal. 2014 Jan;96(1):106-13. PubMed PMID: 24395320. Epub 2014/01/08. eng.

22. Tomaszewski P, Verdonschot N, Bulstra S, Verkerke G. New direct fixation implant for upper-leg prostheses: University Medical Center Groningen; 2012.

23. Tomaszewski PK, Lasnier B, Hannink G, Verkerke GJ, Verdonschot N. Experimental assessment of a new direct fixation implant for artificial limbs. J Mech Behav Biomed Mater. 2013 May;21:77-85. PubMed PMID: 23510969. Epub 2013/03/21. eng.

24. Tomaszewski PK, Verdonschot N, Bulstra SK, Verkerke GJ. A New Osseointegrated Fixation Implant for Amputated Patients. Journal of Biomechanics. 2012 7//;45(0):S322.

25. Shevtsov MA, Galibin OV, Yudintceva NM, Blinova MI, Pinaev GP, Ivanova AA, et al. Two-stage implantation of the skin- and boneintegrated pylon seeded with autologous 
fibroblasts induced into osteoblast differentiation for direct skeletal attachment of limb prostheses. Journal of biomedical materials research Part A. 2014 Sep;102(9):3033-48. PubMed PMID: 24115308. Pubmed Central PMCID: 3969869. Epub 2013/10/12. eng.

26. Marks LJ, Michael JW. Science, medicine, and the future: Artificial limbs. BMJ. 2001 Sep 29;323(7315):732-5. PubMed PMID: 11576982. Pubmed Central PMCID: 1121287. Epub 2001/09/29. eng.

27. Hagberg K, Branemark R. One hundred patients treated with osseointegrated transfemoral amputation prosthesesrehabilitation perspective. Journal of rehabilitation research and development. 2009;46(3):331-44. PubMed PMID: 19675986. Epub 2009/08/14. eng.

28. Hagberg K, Branemark R, Gunterberg B, Rydevik B. Osseointegrated trans-femoral amputation prostheses: Prospective results of general and condition-specific quality of life in 18 patients at 2-year follow-up. Prosthetics and Orthotics International. 2008;32(1):29 41.

29. Jonsson S, Caine-Winterberger K, Branemark $\mathrm{R}$. Osseointegration amputation prostheses on the upper limbs: methods, prosthetics and rehabilitation. Prosthetics and orthotics international. 2011 Jun;35(2):190-200. PubMed PMID: 21697201. Epub 2011/06/24. eng.

30. Palmquist A, Windahl SH, Norlindh B, Branemark R, Thomsen P. Retrieved boneanchored percutaneous amputation prosthesis showing maintained osseointegration after 11 years-a case report. Acta Orthop. 2014 May 5;2014(05). PubMed PMID: 24798110. Epub 2014/05/07. Eng.

31. Hagberg K, Hansson E, Branemark R. Outcome of Percutaneous Osseointegrated Prostheses for Patients With Unilateral Transfemoral Amputation at Two-Year Follow-Up. Archives of physical medicine and rehabilitation. 2014 Jul 24;95(11):2120-7. PubMed PMID: 25064778. Epub 2014/07/30. Eng.

32. Van de Meent H, Hopman MT, Frolke JP. Walking ability and quality of life in subjects with transfemoral amputation: a comparison of osseointegration with socket prostheses. Archives of physical medicine and rehabilitation. 2013 Nov;94(11):2174-8.
PubMed PMID: 23774380. Epub 2013/06/19. eng.

33. Aschoff H, Juhnke D, Al Muderis M, editors. Case presentations of the Integral Leg Prosthesis (ILP): achievements and pitfalls. 26th European Musculoskeletal oncoloy society meeting; 2013; Gothengurg, Sweden.

34. Fitzpatrick N, Smith TJ, Pendegrass CJ, Yeadon R, Ring M, Goodship AE, et al. Intraosseous transcutaneous amputation prosthesis (ITAP) for limb salvage in 4 dogs. Veterinary surgery : VS. 2011 Dec;40(8):90925. PubMed PMID: 22092391. Epub 2011/11/19. eng.

35. Kang NV, Morritt D, Pendegrass C, Blunn G. Use of ITAP implants for prosthetic reconstruction of extra-oral craniofacial defects. Journal of plastic, reconstructive \& aesthetic surgery : JPRAS. 2013 Apr;66(4):497-505. PubMed PMID: 23270664. Epub 2012/12/29. eng.

36. Tomaszewski PK, van Diest M, Bulstra SK, Verdonschot N, Verkerke GJ. Numerical analysis of an osseointegrated prosthesis fixation with reduced bone failure risk and periprosthetic bone loss. Journal of biomechanics. 2012 Jul 26;45(11):1875-80. PubMed PMID: 22677337. Epub 2012/06/09. eng.

37. Tomaszewski PK, Verdonschot N, Bulstra SK, Rietman JS, Verkerke GJ. Simulated bone remodeling around two types of osseointegrated implants for direct fixation of upper-leg prostheses. J Mech Behav Biomed Mater. 2012 Nov;15(0):167-75. PubMed PMID: 23032436. Epub 2012/10/04. eng.

38. Tomaszewski P, Verdonschot N, Bulstra S, Verkerke G, editors. Mechanical Failure Risks and Bone Remodeling after Implantation of Osseointegrated Transfemoral Prostheses. Proceedings of 13th ISPO World Congress; 2010; Liepzig, Germany.

39. Shelton TJ, Beck JP, Bloebaum RD, Bachus KN. Percutaneous osseointegrated prostheses for amputees: Limb compensation in a 12month ovine model. Journal of biomechanics. 2011 Oct 13;44(15):2601-6. PubMed PMID: 21920525. Pubmed Central PMCID: 3190641. Epub 2011/09/17. eng.

40. Jeyapalina S, Beck JP, Bachus KN, Williams DL, Bloebaum RD. Efficacy of a porousstructured titanium subdermal barrier for preventing infection in percutaneous osseointegrated prostheses. Journal of 
orthopaedic research : official publication of the Orthopaedic Research Society. 2012 Aug;30(8):1304-11. PubMed PMID: 22294380. Epub 2012/02/02. eng.

41. Jeyapalina S, Beck JP, Bachus KN, Bloebaum $\mathrm{RD}$. Cortical bone response to the presence of load-bearing percutaneous osseointegrated prostheses. Anat Rec (Hoboken). 2012 Sep;295(9):1437-45. PubMed PMID: 22807281. Epub 2012/07/19. eng.

42. Holt BM, Betz DH, Ford TA, Beck JP, Bloebaum RD, Jeyapalina S. Pig dorsum model for examining impaired wound healing at the skin-implant interface of percutaneous devices. Journal of materials science Materials in medicine. 2013 Jul 6:1-13. PubMed PMID: 23832453. Epub 2013/07/09. Eng.

43. Jeyapalina S, Beck JP, Bloebaum RD, Bachus KN. Progression of Bone Ingrowth and Attachment Strength for Stability of Percutaneous Osseointegrated Prostheses. Clinical orthopaedics and related research. 2013 Nov 21:1-9. PubMed PMID: 24258685. Epub 2013/11/22. Eng.

44. Williams DL, Bloebaum RD, Beck JP, Petti CA. Characterization of bacterial isolates collected from a sheep model of osseointegration. Curr Microbiol. 2010 Dec;61(6):574-83. PubMed PMID: 20458482. Epub 2010/05/12. eng.

45. Holt BM, Bachus KN, Beck JP, Bloebaum $\mathrm{RD}$, Jeyapalina S. Immediate postimplantation skin immobilization decreases skin regression around percutaneous osseointegrated prosthetic implant systems. Journal of biomedical materials research Part A. 2013 Jul;101(7):2075-82. PubMed PMID: 23281016. Epub 2013/01/03. eng.

46. Jeyapalina S, Beck JP, Bachus KN, Chalayon $\mathrm{O}$, Bloebaum RD. Radiographic Evaluation of Bone Adaptation Adjacent to Percutaneous Osseointegrated Prostheses in a Sheep Model. Clinical orthopaedics and related research. 2014 Feb 21:1-12. PubMed PMID: 24557934. Epub 2014/02/22. Eng.

47. Hillock R, Tatum D, E D. Osseointegration Implant Post Coupling With External Prosthetic Limb Continuation of Previous Case Reports "Stage III". Reconstructive review - Joint Implant Surgery \& Research Foundation. 2014;4(2):13-6.

48. Zak A, Hillock R. Anesthesia and Pain Control for Osteointegration Implantation Into the Femur - Stage II Osteointegration
Implant (OI) Skin Coupling Procedure. Joint Implant Surgery \& Research Foundation's. 2014;3(4):67-9.

49. Hillock R, Keggi J, Kennon R, McPherson E, Clyburn T, Brazil D, et al. Stage II Osteointegration Implant (OI) Skin Coupling Procedure. Reconstructive review - Joint Implant Surgery \& Research Foundation. 2013;3(4):62-6.

50. Haggstrom E, Hagberg K, Rydevik B, Branemark R. Vibrotactile evaluation: osseointegrated versus socket-suspended transfemoral prostheses. Journal of rehabilitation research and development. 2013;50(10):1423-34. PubMed PMID: 24699977. Epub 2014/04/05. eng.

51. Cairns N, Frossard L, Hagberg K, Brånemark R. The loading techniques used during static rehabilitation of amputees using osseointegrated fixation. XIIth World Congress of the International Society for Prosthetics and Orthotics; Vancouver, Canada2007. p. 373.

52. Jacobs R, Brånemark R, Olmarker K, Rydevik B, Van Steenberghe D, Branemark P. Evaluation of the psychophysical detection threshold level for vibrotactile and pressure stimulation of prosthetic limbs using bone anchorage or soft tissue support. Prosthetics and Orthotics International. 2000;24(2):13342.

53. Frossard L, Hagberg K, Häggström E, Gow DL, Brånemark R, Pearcy M. Functional Outcome of Transfemoral Amputees Fitted With an Osseointegrated Fixation: Temporal Gait Characteristics. J Prosthet Orthot. 2010;22(1):11-20.

54. Lee W, Frossard L, Hagberg K, Haggstrom E, Brånemark R. Kinetics analysis of transfemoral amputees fitted with osseointegrated fixation performing common activities of daily living. Clin Biomech (Bristol, Avon). 2007;22(6):665-73.

55. Lee WCC, Doocey JM, Brånemark R, Adam CJ, Evans JH, Pearcy MJ, et al. FE stress analysis of the interface between the bone and an osseointegrated implant for amputees Implications to refine the rehabilitation program. Clinical Biomechanics. 2008;23(10):1243-50.

56. Hagberg $\mathrm{K}$, Haggstrom E, Uden M, Branemark R. Socket versus bone-anchored trans-femoral prostheses: hip range of motion and sitting comfort. Prosthetics and orthotics 
international. $2005 \quad$ Aug;29(2):153-63. PubMed PMID: 16281724. Epub 2005/11/12. eng.

57. van Eck CF, McGough RL. Clinical outcome of osseointegrated prostheses for lower extremity amputations: a systematic review of the literature. Current Orthopaedic Practice. 2015;26(4):349-57. PubMed PMID: 01337441-201507000-00006.

58. Nebergall A, Bragdon C, Antonellis A, Karrholm J, Branemark R, Malchau H. Stable fixation of an osseointegated implant system for above-the-knee amputees: titel RSA and radiographic evaluation of migration and bone remodeling in 55 cases. Acta orthopaedica. 2012 Apr;83(2):121-8. PubMed PMID: 22489885. Pubmed Central PMCID: 3339524. Epub 2012/04/12. eng.

59. Tillander J, Hagberg $\mathrm{K}$, Hagberg L, Branemark R. Osseointegrated titanium implants for limb prostheses attachments: infectious complications. Clinical orthopaedics and related research. 2010 Oct;468(10):2781-8. PubMed PMID: 20473597. Pubmed Central PMCID: 2939339. Epub 2010/05/18. eng.

60. Frossard L, Hagberg K, Haggstrom E, Branemark R. Load-relief of walking aids on osseointegrated fixation: Instrument for evidence-based practice. Neural Systems and Rehabilitation Engineering, IEEE Transactions on. 2009;17(1):9-14.

61. Frossard LA, Tranberg R, Haggstrom E, Pearcy M, Branemark R. Load on osseointegrated fixation of a transfemoral amputee during a fall: loading, descent, impact and recovery analysis. Prosthetics and orthotics international. 2010 Mar;34(1):85-97. PubMed PMID: 20196690. Epub 2010/03/04. eng.

62. Frossard LA. Load on osseointegrated fixation of a transfemoral amputee during a fall: Determination of the time and duration of descent. Prosthet Orthot Int. 2010 Dec;34(4):472-87. PubMed PMID: 20961183. Epub 2010/10/22. eng.

63. Lee WC, Frossard LA, Hagberg K, Haggstrom E, Gow DL, Gray S, et al. Magnitude and variability of loading on the osseointegrated implant of transfemoral amputees during walking. Med Eng Phys. 2008 Sep;30(7):825-33. PubMed PMID: 17977050. Epub 2007/11/03. eng.
64. Frossard L, Gow DL, Hagberg K, Cairns N, Contoyannis B, Gray S, et al. Apparatus for monitoring load bearing rehabilitation exercises of a transfemoral amputee fitted with an osseointegrated fixation: a proof-ofconcept study. Gait \& posture. 2010 Feb;31(2):223-8. PubMed PMID: 19926285. Epub 2009/11/21. eng.

65. Frossard L, Haggstrom E, Hagberg K, Branemark P. Load applied on a boneanchored transfemoral prosthesis: characterisation of prosthetic components - A case study Journal of Rehabilitation Research \& Development. 2013;50(5):619-34.

66. Frossard L, Stevenson N, Sullivan J, Uden M, Pearcy M. Categorization of Activities of Daily Living of Lower Limb Amputees During Short-Term Use of a Portable Kinetic Recording System: A Preliminary Study. J Prosthet Orthot. 2011;23(1):2-11.

67. Hagberg K, Häggström E, Jönsson S, Rydevik $\mathrm{B}$, Brånemark R. Osseoperception and Osseointegrated Prosthetic Limbs. In: Gallagher P, Desmond D, MacLachlan M, editors.: Springer London; 2008. p. 131-40.

68. Kumar L, Singh BP, Kamleshwar Singh JR. Osseoperception in Implants Supported Prosthesis - A Review. Online Journal of Medicine and Medical Science Research. 2012;1(1):1-4.

69. Isaacson B, Jeyapalina S. Osseointegration: A review of the fundamentals for assuring cementless skeletal fixation. Orthopedic Research and Reviews. 2014;6:55-65.

70. $\mathrm{Xu} \mathrm{DH}$, Crocombe $\mathrm{AD}, \mathrm{Xu}$ W. Numerical evaluation of bone remodelling associated with trans-femoral osseointegration implant-A 68 month follow-up study. Journal of biomechanics. 2016 Feb 8;49(3):488-92. PubMed PMID: 26776932. Epub 2016/01/19. eng.

71. Lee WC, Doocey JM, Branemark R, Adam CJ, Evans JH, Pearcy MJ, et al. FE stress analysis of the interface between the bone and an osseointegrated implant for amputees-implications to refine the rehabilitation program. Clin Biomech (Bristol, Avon). 2008 Dec;23(10):1243-50. PubMed PMID: 18809231. Epub 2008/09/24. eng.

72. Helgason B, Palsson H, Runarsson TP, Frossard L, Viceconti M. Risk of failure during gait for direct skeletal attachment of a femoral prosthesis: a finite element study. Medical engineering \& physics. 2009 
Jun;31(5):595-600. PubMed PMID: 19150253. Epub 2009/01/20. eng.

73. Vertriest S, Coorevits P, Hagberg K, Branemark R, Haggstrom E, Vanderstraeten $\mathrm{G}$, et al. Static load bearing exercises of individuals with transfemoral amputation fitted with an osseointegrated implant: reliability of kinetic data. IEEE transactions on neural systems and rehabilitation engineering : a publication of the IEEE Engineering in Medicine and Biology Society. 2015 May;23(3):423-30. PubMed PMID: 25051557. Epub 2014/07/23. eng.

74. Vertriest S, Coorevits P, Hagberg K, Branemark R, Haggstrom EE, Vanderstraeten $\mathrm{G}$, et al. Static load bearing exercises of individuals with transfemoral amputation fitted with an osseointegrated implant: Loading compliance. Prosthet Orthot Int. 2016 Apr 26. PubMed PMID: 27117014. Epub 2016/04/28. Eng.

75. Frossard L, Hagberg K, Haggstrom E, Branemark R. Load-relief of walking aids on osseointegrated fixation: instrument for evidence-based practice. IEEE transactions on neural systems and rehabilitation engineering : a publication of the IEEE Engineering in Medicine and Biology Society. 2009 Feb;17(1):9-14. PubMed PMID: 19211318. Epub 2009/02/13. eng.

76. Frossard L, Stevenson N, Smeathers J, Lee Gow D, Gray S, Sullivan J, et al. Daily activities of a transfemoral amputee fitted with osseointegrated fixation: continuous recording of the loading for an evidence-based practice. Kinesitherapie Revue. 2006;6(56-57):53-62.

77. Schwarze M, Hurschler C, Seehaus F, Correa $\mathrm{T}$, Welke B. Influence of transfemoral amputation length on resulting loads at the osseointegrated prosthesis fixation during walking and falling. Clin Biomech (Bristol, Avon). 2013; In press(0).

78. Haket LM, Frolke JP, Verdonschot N, Tomaszewski PK, van de Meent H. Periprosthetic cortical bone remodeling in patients with an osseointegrated leg prosthesis. Journal of orthopaedic research : official publication of the Orthopaedic Research Society. 2016 Jul 28. PubMed PMID: 27467497. Epub 2016/07/29. Eng.

79. Al Muderis M, Tetsworth K, Khemka A, Wilmot S, Bosley B, Lord SJ, et al. The Osseointegration Group of Australia Accelerated Protocol (OGAAP-1) for twostage osseointegrated reconstruction of amputated limbs. Bone \& Joint Journal. 2016 2016-07-01 00:00:00;98-B(7):952-60.

80. Aschoff H-H, McGough R. The Endo-Exo Femoral Prosthesis: a new rehabilitation concept following above knee amputation. Journal of Bone \& Joint Surgery, British Volume. 2012 September 1, 2012;94-B(SUPP XXXIX):77.

81. Berlin Ö, Bergh P, Dalen M, Eriksson S, Hagberg K, Inerot $S$, et al. Osseointegration in transfemoral amputees: the gothenburg experience. Journal of Bone \& Joint Surgery, British Volume; April 1, 20122012. p. 55.

82. Leijendekkers RA, van Hinte G, Frolke JP, van de Meent H, Nijhuis-van der Sanden MW, Staal JB. Comparison of bone-anchored prostheses and socket prostheses for patients with a lower extremity amputation: a systematic review. Disability and rehabilitation. 2016 Aug 5:1-14. PubMed PMID: 27494092. Epub 2016/08/06. Eng.

\section{Appendix I: Search Strategy}

First, the search strategy to find relevant publications will rely on selection of databases to be searched including, Medline/Pubmed, CINAHL, Web of science, Google Scholar, EMBASE, SCOPUS, LILACS and ProQuest Dissertations and Theses Global.

Then, each database will be searched individually using relevant search syntaxes and combining key MeSH and other database-specific subject terms together with commonly used keywords provided in Table 1. Using these keywords will be paramount giving the proliferation of general terms referring to bone-anchored prosthesis and individual acronyms for each fixation. 
Table 1. Key MeSH terms and commonly used keywords for key aspects of the treatment and rehabilitation program

\begin{tabular}{|c|c|}
\hline MeSH terms & Commonly used keywords \\
\hline \multicolumn{2}{|l|}{ Treatment - Population } \\
\hline $\begin{array}{ll} & \text { Adolescent } \\
\text { - } & \text { Adult+ } \\
\text { - } & \text { Amputees } \\
\text { - } & \text { Humans }\end{array}$ & $\begin{array}{ll}\text { - } & \text { Above-the-knee prosthesis } \\
\text { - } & \text { Individuals with transfemoral amputation } \\
\text { - } & \text { Limb prostheses } \\
\text { - } & \text { Prosthetic limb } \\
\text { - } & \text { Prosthetics } \\
\text { - } & \text { TFA } \\
\text { - } & \text { Transfemoral amputees } \\
\text { - } & \text { Transfemoral prosthesis } \\
\text { - } & \text { Unilateral amputation }\end{array}$ \\
\hline \multicolumn{2}{|l|}{ Treatment - Fixation } \\
\hline $\begin{array}{ll}\text { - } & \text { Amputation } \\
\text { - } & \text { Amputation stumps } \\
\text { - } & \text { Osseointegration } \\
\text { - } & \text { Bone and bones } \\
\text { - } & \text { Lower extremity } \\
\text { - } & \text { Prosthedics } \\
& \text { implants+ } \\
\text { - } & \text { Prosthesis failure } \\
\text { - } & \text { Reconstructive surgical } \\
& \text { procedures+ } \\
\text { - } & \text { Titanium } \\
& \end{array}$ & $\begin{array}{l}\text { - } \text { BAP: Bone-anchorage/anchored prosthesis } \\
\text { - } \quad \text { Direct bone attachment } \\
\text { - } \text { ESA: Direct skeletal attachment } \\
\text { - } \quad \text { Endo-exo prosthesis } \\
\text { - ILP: Integral leg prosthesis } \\
\text { - Implant supported prosthesis } \\
\text { - Intramedullary attachment } \\
\text { - ITtraosseus fixation/implant/device } \\
\text { - } \text { OGAAP: Osseointegration Group of Australia Accelerated Protocol } \\
\text { - OIP: Osseointegrated (femoral) prosthesis } \\
\text { - OPL: Osseointegrated prosthesis leg } \\
\text { - OPRA: Osseointegrated Prosthesis for the Rehabilitation of Amputees } \\
\text { - Percutaneous fixation/implant/device } \\
\text { - POP: Percutaneous osseointegrated prostheses } \\
\text { - Press-fit } \\
\text { - } \quad \text { Srosthetic pylon } \\
\text { - Screw-type } \\
\text { - Skeletal attachment } \\
\text { - Skin-implant bone interface } \\
\text { Transcutaneous }\end{array}$ \\
\hline \multicolumn{2}{|l|}{ Rehabilitation program } \\
\hline $\begin{array}{ll}\text { - } & \text { Canes } \\
\text { - } & \text { Crutches } \\
\text { - } & \text { Gait } \\
\text { - } & \text { Monitoring, ambulatory } \\
\text { - } & \text { Rehabilitation+ } \\
\text { - } & \text { Weight-bearing }\end{array}$ & $\begin{array}{l}\text { - } \quad \text { Dynamic load bearing exercises } \\
\text { - } \quad \text { Gait training } \\
\text { - } \quad \text { Monitoring device } \\
\text { - } \quad \text { Parallel bars } \\
\text { - Partial weight bearing } \\
\text { - Prosthetic gait } \\
\text { - } \quad \text { Prosthetic rehabilitation } \\
\text { - } \quad \text { Static load bearing exercises } \\
\text { - Training prosthesis } \\
\text { - } \quad \text { Walking aids } \\
\text { - Walking sticks }\end{array}$ \\
\hline
\end{tabular}


Appendix II: Draft study details, characteristics, and results extraction instrument/s Data extraction instrument/s

Reference data extraction form

\begin{tabular}{|l|l|}
\hline Full reference selected & Completion rate \\
\hline & \\
& \\
\hline
\end{tabular}

\begin{tabular}{|c|c|c|c|}
\hline \multicolumn{4}{|c|}{ Reference data and dataset } \\
\hline Section & Variables & Unit & Information \\
\hline 1 & Data entry & & \\
\hline 1.1 & Publication ID & $(\#)$ & \\
\hline 1.2 & Reviewer & (txt) & \\
\hline 1.3 & Date & (dd/mm/yyyy) & \\
\hline 2 & Reference & & \\
\hline 2.1 & Title & (txt) & \\
\hline 2.2 & Author/s & (txt) & \\
\hline 2.3 & Affiliation & $(\mathrm{txt})$ & \\
\hline 2.4 & Country & (txt) & \\
\hline 2.5 & City of origin & (txt) & \\
\hline 2.6 & Year of publication & (txt) & \\
\hline 2.7 & EndNote $\mathrm{Nb}$ & (txt) & \\
\hline 2.8 & Dataset ID & $(\#)$ & \\
\hline 3 & Comments & & \\
\hline 3.1 & Comment 01 - Aims of study & (txt) & \\
\hline 3.2 & Comment 02 - Methodology/design & (txt) & \\
\hline 3.3 & Comment 03 - Concept/intervention & (txt) & \\
\hline 3.4 & Comment 04 - Key findings & (txt) & \\
\hline 4 & Treatment & & \\
\hline 4.1 & Population & & \\
\hline 4.1 .1 & Level of amputation & (txt) & \\
\hline 4.1 .2 & Causes of amputation & (txt) & \\
\hline 4.2 & Fixation & & \\
\hline 4.2 .1 & Type & $(\mathrm{txt})$ & \\
\hline 4.2 .2 & Name & $(\mathrm{txt})$ & \\
\hline 4.2 .3 & Brand & $(\mathrm{txt})$ & \\
\hline 4.2 .4 & Dimensions & $(\mathrm{cm})$ & \\
\hline
\end{tabular}




\begin{tabular}{|c|c|c|c|}
\hline 4.3 & Surgery & & \\
\hline 4.3 .1 & Number of surgical procedures & (\#) & \\
\hline 5 & Rehabilitation program & & \\
\hline 5.1 & Static load bearing exercises & & \\
\hline 5.1 .1 & Training prosthesis & & \\
\hline 5.1.1.1 & Shape of distal end & $(\mathrm{txt})$ & \\
\hline 5.1 .1 .2 & Length & $(\mathrm{txt})$ & \\
\hline 5.1 .2 & Loading time & & \\
\hline 5.1 .2 .1 & $\mathrm{Nb}$ of cessions & $(\# / d)$ & \\
\hline 5.1 .2 .2 & Duration & (min/cession) & \\
\hline 5.1 .2 .3 & Total duration & $(\mathrm{min} / \mathrm{d})$ & \\
\hline 5.1 .3 & Loading progression & & \\
\hline 5.1.3.1 & Elapse S1-S2 & (wks) & \\
\hline 5.1 .3 .2 & Start post $\mathrm{S} 2$ & (wks) & \\
\hline 5.1 .3 .3 & Starting load & $(\mathrm{kg})$ & \\
\hline 5.1 .3 .4 & Magnitude & $(\mathrm{kg} / \mathrm{wk})$ & \\
\hline 5.1.3.5 & Application & (dd) & \\
\hline 5.1.3.6 & End & (wks) & \\
\hline 5.1 .4 & Monitoring of loading & & \\
\hline 5.1 .4 .1 & Device & $(\mathrm{txt})$ & \\
\hline 5.1 .4 .2 & Apparatus & $(\mathrm{txt})$ & \\
\hline 5.1 .4 .3 & Height adjustment & $(\mathrm{txt})$ & \\
\hline 5.1.4.4 & Hand position & $(\mathrm{txt})$ & \\
\hline 5.1 .5 & Direction of loading & & \\
\hline 5.1.5.1 & Axial & $(\mathrm{Y} / \mathrm{N} / \mathrm{U})$ & \\
\hline 5.1.5.2 & Rotation & $(\mathrm{Y} / \mathrm{N} / \mathrm{U})$ & \\
\hline 5.1 .6 & Instructions to participants & & \\
\hline 5.1 .6 .1 & List & $(\mathrm{txt})$ & \\
\hline 5.1 .7 & Regulators & & \\
\hline 5.1.7.1 & Pain & $(\mathrm{Y} / \mathrm{N} / \mathrm{U})$ & \\
\hline 5.1.7.2 & Monitoring & $(\mathrm{txt})$ & \\
\hline 5.1.7.3 & Threshold & $(\#)$ & \\
\hline 5.2 & Dynamic load bearing exercises & & \\
\hline 5.2 .1 & Type of exercises & $(\mathrm{txt})$ & \\
\hline 5.2 .2 & Aim of exercises & $(\mathrm{txt})$ & \\
\hline 5.2 .3 & Duration & & \\
\hline 5.2 .3 .1 & Start post $\mathrm{S} 2$ & (wks) & \\
\hline 5.2 .3 .2 & End & (wks) & \\
\hline 5.2 .4 & Regulators & $(\mathrm{txt})$ & \\
\hline
\end{tabular}




\begin{tabular}{|l|c|c|c|}
\hline 5.3 & Load bearing with walking aids & $(\mathrm{wks})$ & \\
\hline 5.3 .0 & Start - Time since last surgery & $(\mathrm{wks})$ & \\
\hline 5.3 .0 & End - Time since last surgery & $(\mathrm{Y} / \mathrm{N} / \mathrm{U})$ & \\
\hline 5.3 .1 & Parallel bars & $(\mathrm{wks})$ & \\
\hline 5.3 .1 .1 & Use & & \\
\hline 5.3 .1 .2 & Time after last surgery & $(\mathrm{Y} / \mathrm{N} / \mathrm{U})$ & \\
\hline 5.3 .2 & Two crutches & & \\
\hline 5.3 .2 .1 & Use & $(\mathrm{Y} / \mathrm{N} / \mathrm{U})$ & \\
\hline 5.3 .2 .2 & Time after last surgery & $(\mathrm{wks})$ & \\
\hline 5.3 .3 & One crutch & & \\
\hline 5.3 .3 .1 & Use & $(\mathrm{Y} / \mathrm{N} / \mathrm{U})$ & \\
\hline 5.3 .3 .2 & Time after last surgery & $(\mathrm{wks})$ & \\
\hline 5.3 .4 & On stick & & \\
\hline 5.3 .4 .1 & Use & $(\mathrm{Y} / \mathrm{N} / \mathrm{U})$ & \\
\hline 5.3 .4 .2 & Time after last surgery & & \\
\hline 5.3 .5 & Regulator & $(\mathrm{txt})$ & \\
\hline 5.3 .5 .1 & End based on X-Ray & $(\mathrm{txt})$ & \\
\hline 6 & Appraisal & & \\
\hline 6.1 & Source & $(\mathrm{txt})$ & \\
\hline 6.2 & Type & & \\
\hline 6.3 & Outcome & & \\
\hline 6.3 .1 & Reviewer 1 & & \\
\hline 6.3 .2 & Reviewer 2 & & \\
\hline 6.3 .3 & Reviewers & & \\
\hline & & & \\
\hline
\end{tabular}

